\title{
ANTARA MUNASAKHAH DAN AHLI WARIS PENGGANTI PADA PUTUSAN NOMOR: 0311/PDT.G/2009/PA.SEL.
}

\author{
BETWEEN MUNASAKHAH AND SUBSTITUTE HEIR IN \\ DECISION NUMBER : 0311/PDT.G/2009/PA.SEL. \\ Fatahullah \\ Fakultas Hukum Universitas Mataram \\ Email : ullaw84@yahoo.co.id \\ Sugiyarno \\ Fakultas Hukum Universitas Mataram \\ Email : sugiyarno@unram.ac.id \\ Ita Surayya \\ Dosen Fakultas Hukum Universitas Mataram \\ Email : itasurayya@unram.ac.id
}

Naskah diterima : 12/12/2017; direvisi : 26/02/2018; disetujui : 27/04/2018

\begin{abstract}
The law of inheritance is a rule concerning the process of forwarding the estate to the living heirs. In principle when the heirs died then automatically open the process of transition of heritage treasures. But sometimes in practice the automatic principle is not implemented immediately but is overrun by some heirs for a long time. This can be due to deliberate elements and / or because the heirs do not understand each other's rights. For example in a case that was decided by the Religious Court of Selong Lombok Timur Number 0311 / Pdt.G / 2009 / PA.SEL. The type of normative research that examines the various rules of Islamic law and the rules oflegislation applicable in Indonesia, especially about the legacy of munasakhah and Substitute heirs. This research uses the approach of statuta approach, conceptual approach, analytical approach and case approach. From the research results revealed that the judge based his decision on article 185 Compilation of Islamic Law. So the right of Amaq Yang's main heirs to be the right of their successor heirs. The judge in this case is too formalistic to apply only the law and does not consider other aspects, example the neglect of takharuj ever happened between the heirs.
\end{abstract}

Keywords: Heirs, Substitutes, Judgments of the Religious Courts

\begin{abstract}
Abstrak
Hukum waris merupakan aturan tentang proses penerusan harta pewaris kepada ahli waris yang masih hidup. Secara prinsip ketika pewaris meninggal dunia maka secara otomatis terbuka proses peralihan harta peninggalannya. Akan tetapi terkadang dalam prakteknya prinsip otomatis tadi tidak dilaksanakan seketika tetapi dikuasai oleh sebagian ahli waris untuk waktu yang lama. Hal ini bisa disebabkan karena unsur kesengajaan dan atau karena ahli waris tidak paham hak masing-masing. Misalnya dalam perkara yang diputus oleh Pengadilan Agama Selong Lombok Timur Nomor 0311/Pdt.G/2009/PA.SEL. Jenis penelitian normatif yang mengkaji berbagai aturan dalam Hukum Islam maupun aturan perundang-undangan yang berlaku di Indonesia yang khususnya tentang kewarisan munasakhah dan Ahli Waris Pengganti. Penelitian ini menggunakan metode pendekatan perundangundangan, pendekatan konsep, pendekatan analisis dan pendekatan kasus. Dari hasil penelitian terungkap bahwa hakim mendasarkan putusannya pada pasal 185 Kompilasi Hukum Islam. Sehingga hak ahli waris utama Amaq Yang menjadi hak
\end{abstract}


Fatahullah, Sugiyarno \& Ita Surayya|Antara Munasakhah Dan Ahli Waris Pengganti Pada Putussan.......

ahli waris penggantinya masing-masing. Hakim dalam perkara ini terlalu formalistik yakni hanya bersifat menerapkan hukum dan tidak mempertimbangkan aspek lain, misalnya diabaikannya takharuj yang pernah terjadi antara ahli waris.

\section{Kata Kunci: Ahli Waris, Pengganti, Putusan Pengadilan Agama}

\section{PENDAHULUAN}

Kewarisanmerupakan proses penerusan kekayaan manusia yang dilakukan secara turun temurun dari pewaris kepada ahli waris yang masih hidup. Secara hukum setiap ahli waris memiliki hak yang sama untuk memperoleh warisan sebagaimana firman Allah SWT. dalam Al-Qur'an surat Surat An-Nisa ayat (7) yakni:

"Laki-lakiberhak memperoleh harta dari peninggalan ibu bapaknya dan wanita pun berhak memperoleh bagian dari harta peniggalan ibu, bapaknya dan kerabatnya, baik sedikit atau banyak menurut bagian yang telah ditetapkan.

Qur'an Surat an-Nisa ayat 7 diatas telah menentukan bahwa baik ahli waris laki-laki maupun ahli waris perempuan memiliki kedudukan yang sama atas harta peninggalan pewaris. Masalah harta peninggalan/warisan, sering menjadi sumber sengketa dalam keluarga. Terutama untuk menentukan siapa saja yang berhak dan tidak berhak mendapat warisan dan besar kecilnya bagian dari masing-masing ahli waris yang pada gilirannya bisa menimbulkan keretakan keluarga. Karena para ahli waris bukanlah orang lain akan tetapi masih dalam satu keturunan/ keluarga. Untuk itulah perlu ketelitian dan kehati-hatian dalam melakukan pembagian warisan. Bisa jadi menurut salah satu pihak sudah adil sedangkan menurut pihak lain menganggap tidak adil. Karena itu, agama Islam datang membawa ketentuan-ketentuan dari Allah SWT dalam hal waris-mewarisi ini. Agama/ hukum Islam telah mengatur masalah secara terperinci tentang hak-hak masing ahli waris sebagaimana dijelaskan dalam QS. an-Nisa ayat (11)

Allah mensyari'atkan bagimu tentang (pembagian pusaka untuk) anak-anak- mu. Yaitu bagian seorang anak lelaki sama dengan bagian dua orang anak perempuan; dan jika anak itu semuanya perempuan lebih dari dua, Maka bagi mereka dua pertiga dari harta yang ditinggalkan; jika anak perempuan itu seorang saja, maka ia memperoleh separo harta. dan untuk dua orang ibu-bapak, bagi masing-masingnya seperenam dari harta yang ditinggalkan, jika yang meninggal itu mempunyai anak; jika orang yang meninggal tidak mempunyai anak dan ia diwarisi oleh ibu-bapaknya (saja), maka ibunya mendapat sepertiga; jika yang meninggal itu mempunyai beberapa saudara, maka ibunya mendapat seperenam. (Pembagian-pembagian tersebut di atas) sesudah dipenuhi wasiat yang ia buat atau (dan) sesudah dibayar hutangnya. (Tentang) orang tuamu dan anak-anakmu, kamu tidak mengetahui siapa di antara mereka yang lebih dekat (banyak) manfaatnya bagimu. ini adalah ketetapan dari Allah. Sesungguhnya Allah maha mengetahui lagi maha bijaksana.

Hak-hak ahli waris dalam hukum kewarisan Islam pada dasarnya dinyatakan dalam jumlah atau bagian tertentu dengan angka yang pasti. Angka pasti tersebut dinyatakan dalam al-Qur'an sebagai sumber dan rujukan utama bagi hukum kewarisan. Islam dengan syariat kewarisannya telah secara detail menjelaskan dan mengajarkan umatnya tentang bagaimana cara menyelesaikan dan memindahkan harta peninggalan pewarisnya terhadap ahli warisnya. Termasuk di dalamnya kasus kewarisan munasakhah yang tertunda pembagiannya sebagai akibat harta warisan itu tidak cepat dibagikan. Padahal, pembagian 
harta warisan sebagaimana yang telah ditetapkan oleh Allah swt. di dalam kitab-Nya al Qur'an (sepanjang hokum faraidh) harus dipercepat, karena sebelum dibagi, maka (berarti) harta peninggalan itu belum dimiliki oleh siapapun juga, sebab harta itu masih bersyarikat dengan semua ahli waris. Terkadang di antara ahli waris itu terdapat pula anak-anak yatim, maka dengan penyegeraan melakukan pembagian harta warisan tersebut, menurut aturan ilmu faraidh, terhindarlah orang dari pada mengambil dan memakan hak dan milik orang lain dan anak-anak yatim tersebut dengan jalan yang tidak halal.

Seringkali dalam kenyataan di masyarakat, ditemukan kasus seseorang meninggal dunia, tetapi harta warisannya tidak segera dibagikan kepada para ahli warisnya yang berhak. Tidak berapa lama kemudian, di antara ahli warisnya ada yang menyusul wafat sebelum harta warisan yang wafat pertama tadi dibagikan. Selanjutnya di kemudian hari, di antara para ahli waris dari yang wafat pertama maupun ahli waris dari yang wafat belakangan tidak jarang terjadi perselisihan karena masing-masing mengklaim memiliki hak atas harta harta warisan. Selanjutnya ketika dilakukan pembagian baik secara langsung oleh masing-masing ahli waris maupun gugatan melalui pengadilan ternyata menyisakan masalah bagi ahli waris terkait dengan "pengabaian hak sebagian ahli waris", baik hak sebagai ahli waris maupun porsi atau bagian masing-masing ahli waris. Kasus seperti ini dalam hukum kewarisan Islam disebut dengan kasus kewarisan munasakhah. Padahal, pembagian harta warisan sebagaimana yang telah ditetapkan oleh Allah swt. di dalam al Qur'an harus dipercepat, karena sebelum dibagi, maka (berarti) harta peninggalan itu belum dimiliki oleh siapapun juga atau milik bersama (bersyarikat) diantara para ahli waris. Bisa juga terjadi kasus yang hampir sama yakni seorang anak yang seharusnya menjadi ahli waris dari bapak/ibunya meninggal terlebih dahulu daripada bapak/ ibunya dan anak yang meninggal tersebut, disamping meninggalkan bapak-ibunya juga meninggakan anak-istri maupun kakak-adiknya. Secara fiqih Islam anak yang meninggal duluan tersebut tidak berhak mandapatkan warisan dari bapakibunya karena tidak memenuhi syarat sementara anak yang ditinggalkannya terhijab oleh adanya saudaranya. Sehingga ketika terjadi kasus seperti ini maka terkadang menimbulkan ketidakadilan dan kecemburuan antar ahli waris. Maka lahirlah konsep ahli waris pengganti yang diatur melalui pasal 185 Kompilasi Hukum Islam (KHI) dan dibeberapa negara menegenalnya dengan konsep wasiat wajibah untuk anak dan keturunan dari anak yang meninggal duluan tersebut.

Dalam suatu kasus yang telah diputus oleh Pengadilan Agama Selong Lombok Timur Nusa Tenggara Barat (selanjutnya disebut PA Selong) Nomor: 0311/Pdt.G/2009/PA.SEL. Perkara tersebut sangat menarik untuk diteliti lebih lanjut dikarenakan kronologis kasus tersebut yakni jauhnya rentang waktu meninggalnya pewaris dengan dilakukankanya pembagian warisan oleh PA Selong yakni 69 tahun. Sehingga tidak heran ahli waris dalam kasus tersebut sangat kompleks dikarenakan sudah sampai pada keturunan keempat dari pewaris. sehingga Hakim PA Selong tidak membedakan pewarisan munasakhah dengan pewarisan ahli waris pengganti. Hal ini kemudian dilanjutkan dengan terjadinya kerancuan amar eksekusi putusan tersebut. atau juru sita yang melakukan eksekusi mengambil jalan pintas dengan hanya mengeksekusi pada golongan pertama (ahli waris utama) sementara ahli waris utama tersebut semua sudah lama meninggal dunia. Dan yang saling berperkara sekarang adalah ahli waris golongan ke 4. Sepatutnya hakim 
Pengadilan Agama dalam memutus suatu kasus tidak hanya menerapkan hukum tetapi juga bisa menciptakan hukum baru dengan memperhatikan aspek kepastian hukum, keadilan dan juga aspek manfaat dan mudharatnya bagi para pihak yang berperkara. Atas dasar hal tersebut, maka permasalahan dalam tulisan ini adalah sebagai berikut: pertama, Apakah dasar pertimbangan hukum Hakim Pengadilan Selong dalam memutus perkara nomor: 0311/Pdt.G/2009/PA.SEL. kedua, bagaimana analisis putusan tersebut menurut hukum kewarisan Islam terhadap penyelesaian kewarisan munasakhah dan ahli waris pengganti.

Tulisan ini merupakan hasil dari penelitian hukum normatif yakni mengkaji norma-norma hukum Islam seperti Al-Qur'an dan Hadist dan norma transformatifnya dalam hasil ijtihad ulama, aturan perundang-undangan serta putusan pengadilan khususnya putusan Pengadilan Agama Selong Lombok Timur No. 311/Pdt.G/2009/PA.SEL dan putusan Mahkamah Agung No. 16 K/AG/2011 maupun penelitian-penelitian terdahulu yang relevan dengan topik penelitian. Menggunakan Pendekatan Perundangundangan (statute approach), Pendekatan Konsep (conceptual approach), Pendekatan Analitis (analitycal Approach). dan Pendekatan Kasus (Case Approach).

\section{PEMBAHASAN}

\section{Konsepsi Hukum Kewarisan Islam}

Secara teoritis hukum waris Islam sering juga disebut sebagai faraidh yakni bagian yang telah dipastikan atau ditentukan kadarnya. Ada beberapa pendapat tentang definisi faraidh tersebut. Menurut Muhammad al-Syarbiny ilmu faraidh adalah ilmu fiqh yang berkaitan dengan pewarisan, pengetaahuan tentang cara perhitungan yang dapat menyelesaiakan pewarisan tersebut, dan pengetahuan tentang bagian-bagian yang wajib dari harta peninggalan bagi setiap pemilik hak waris (ahli waris) - Sedangkan pada Pasal 171 huruf a Kompilasi Hukum Islam (KHI) hukum kewarisan adalah hukum yang mengatur tentang pemindahan hak pemilikan harta peninggalan (tirkah) pewaris, menentukan siapa-siapa yang berhak menjadi ahli waris dan berapa bagiannya masing-masing. Jadi Hukum kewarisan Islam adalah aturan syariat Islam tentang berpindahnya hak kepemilikan dari pewaris kepada ahli warisnya yang masih hidup baik yang ditinggalkan itu berupa uang, tanah atau apapun yang berupa hak-hak milik yang sah/legal.

Unsur-unsur kewarisan Islam adalah adanya pewaris, adanya ahli waris, dan adanya harta warisan. Ahli waris terdiri dari 25 (dua puluh lima) golongan, yang terdiri dari 15 (lima belas) golongan dari ahli waris laki-laki antara lain; duda, anak, cucu, ayah, kakek, saudara, keponakan, paman, sepupu dan memerdekakan budak. Sedangkan dari golongan perempuan terdiri dari 10 (sepuluh golongan) antara lain: janda, anak, ibu, ibunya ibu, saudara dan memerdekakan budak. Akan tetapi tidak seluruh ahli waris akan mendapatkan bagian bagian warisan, hanya ahli waris tertentu saja disebabkan karena prinsip keutamaan. Prinsip keutamaan ini sesuai dengan ketentuan dalam Pasal 147 ayat (2) KHI menyebutkan:

"apabila semua ahli waris ada, maka yang berhak mendapatkan warisan hanya: anak, ayah, ibu, janda atau duda"

Disamping karena keutamaan diatas, ada sebab penghalang seseorang tidak mendapat bagian warisan sebagaimana dijelaskan dalam Pasal $173 \mathrm{KHI}$ yakni:

"seseorang terhalang menjadi ahli waris apabila dengan putusan Hakim yang telah mempunyai kekuatan hukum tetap, dihukum karena:

a. Dipersalahkan telah membunuh atau mencoba membunuh atau mengani- 
aya berat pada pewaris.

b. Dipersalahkan secara memfitnah telah mengajukan pengaduan bahwa pewaris telah melakukan suatu kejahatan yang diancam dengan hukuman 5 tahun penjara atau hukuman yang lebih berat.

Sedangkan dalam hukum Islam ada 3 sebab seseorang terhalang mendapatkan warisan, yaitu:

a. Sebab budak

b. Sebab Pembunuhan, sebagaimana Rasulullah bersabda "tidaklah seorang pembunuh berhak mewarisi harta orang yang dibunuhnya"

c. Sebab perbedaan agama

"orang Islam tidak punya hak waris atas orang kafir, orang kafir tidak punya hak waris atas orang Islam" (HR. BukhariMuslim).

Duduk Perkara Dan Dasar Pertimbangan Majelis Hakim Terhadap Kasus Nomor 0311/Pdt.G/2009/PA.SEL.

Putusan dalam kasus ini berawal dari sengketa warisan (faraid) antara ahli waris AMAQ YANG yang meninggal tahun 1940. Pada saat meninggal tersebut AMAQ YANG meninggal 4 orang anak sebagai ahli warisnya yaitu (1). LAQ YANG; (2). AMAQ JAENG; (3). INAQ MLA; dan (4). AMAQ MAHRIP. Ketika meninggal tahun 1940 tersebut harta warisan AMAQ YANG tidak langsung dilakukan pembagian warisan sesuai dengan asas ijbari dan asas kewarisan ada karena ada kematian. Akan tetapi harta warisan tersebut dikuasai secara turun temurun oleh sebagian ahli waris. Hal seperti ini dalam hukum faraidh disebut dengan kewarisan munashakah yaitu belum terbaginya harta warisan ahli waris dalam jangka waktu yang lama sampai-sampai ada sebagian ahli waris yang meninggal dunia dan meninggalkan haknya.
Masing-masing ahli waris dari AMAQ YANG memiliki ahli waris yaitu sebagai berikut:

1. LAQ YANG BIN AMAQ YANG yang telah meninggal dunia dengan meninggalkan ahliwaris sebagaiberikut: 1.1. NAHLI BIN AMAQ MAJA yang telah meninggal dunia dengan meninggalkan ahli waris sebagai berikut:

\subsubsection{INAQ DRUM BINTI} AMAQ NAHLI meninggal dengan meninggalkan ahli waris: (1). Amaq Hidayati; (2). Inaq Suyuti; (3). Inaq Ulpa; (4). Maemunah; dan (5). Jaenudin

1.1.2. AMAQ MUNAEN meninggal dengan meninggalkan ahli waris: (1). Inaq Solihin; (2). Maerun; (3). Jaelani; dan (4). Haelani.

\subsubsection{INAQ DUSUKI;}

\subsubsection{HAJJAH HAMDIAH;}

\subsubsection{INAQ SOH.}

1.2. INAQ INA telah meninggal dunia dan tidak memiliki anaka (puntung)

1.3. AMAQ PURNA meninggal dengan meninggalkan ahli waris:

\subsubsection{HATIMAH}

1.3.2. INAQ HAFIZUDIN meninggal dengan meninggalkan ahli waris: (1). Pahriah; (2). Awaludin; (3). Pahmiah; (4). Mashuda; (5). M. Nasir; (6). Samsul; dan (7). Sarah

1.3.3. AMAQ BAHRAEN meninggal dengan meninggalkan ahli waris: (1). Junaedi; (2). Asmuni; dan (3). Huriati.

1.4. AMAQ MUNARAH meninggal dengan meninggalkan ahli waris: (1). Haji Abdullah; dan (2). Amaq Hafizudin. 
Fatahullah, Sugiyarno \& Ita Surayya|Antara Munasakhah Dan Ahli Waris Pengganti Pada Putussan.......

1.5. INAQ IMAT meninggal dengan meninggalkan ahli waris: (1). Hajjah Hudni.

1.6. ACEH meninggal tanpa meninggalkan ahli waris.

2. AMAQ JAENG BIN AMAQ YANG meninggal dengan meninggalkan ahli waris:

2.1. INAQ MISRUN;

2.2. INAQ RUHUN; dan

2.3. INAQ SIROJUDIN.

3. INAQ MLA BIN AMAQ YANG meninggal dengan meninggalkan ahli waris:

3.1. HAJI ROSIDI meninggal dengan meninggalkan ahli waris: (1). Inar telah meninggal tanpa meninggalkan anak; (2). Haji Nurudin; (3). Inaq Pajariah; (4). Hajjah Apsah; (5). Inaq Nurul; (6). Amaq Amzan telah meninggal dengan meninggalkan anak (Mustahniah dan Muksan); (7). InaqHazani;(8).AmaqMusannatelah meninggal dunia dan meninggalkan anak (Musanna, Rohana, Tohuroh, Muntaha, Masturi, dan Purkon); dan (9).InaqHuriahtelahmeninggaldunia dan meninggalkan anak yaitu Pe Her.

3.2. HAJI ABDUL GANI meninggal dengan meninggalkan ahliwaris yaitu Imah.

\subsection{AMAQ MASHUN}

3.4. INAQRISNAEN meninggaldengan meninggalkan ahli waris: (1). Inaq Harbulan; (2). Inaq Wandi; dan (3). Amaq Wirdainitelahmeninggaldunia danmeninggalkananak(Wirdaini, $M$. NazirudindanHarmuzi); dan(4).Inaq Saleha.

\subsection{AMAQ SERUN}

3.6. INAQ TRUM

4. AMAQ MAHRIP BIN AMAQ YANG meninggal dengan meninggalkan ahli waris:

4.1. HAJI ANWAR telah meninggal dunia dan meninggalkan anak: (1). Hajjah Marhumah; (2). Hajjah Mahmudah; (3). Hajjah Hilliati;
(4). Hajjah Saripah; dan (5). Hajjah Rohidah

4.2. HAJI NURUDIN.

Ketika AMAQ YANG meninggal dunia pada tahun 1940, disamping meninggalkan ahli waris sebagaimana disebutkan diatas juga meninggalkan harta warisan yang terdiri dari:

1. Tanah Kebun klas II seluas 0,255 hektar atas nama Amaq Jaeng

2. Tanah Sawah klas IV seluas 0,600 hektar atas nama Amaq Jaeng

3. Tanah Sawah klas II seluas 0,625 hektar atas nama Amaq Jaeng

4. Tanah Sawah klas II seluas 1,245 hektar atas nama Amaq Jaeng

5. TanahSawahklasIseluas 1,660hektar atas nama Amaq Jaeng

6. TanahPekaranganseluaskuranglebih 6 are yang dikuasai oleh Inaq Munaen dan Inaq Dusuki.

Adapun dasar pertimbangan hukum hakim Pengadilan Agama Selong dalam membuat keputusan terhadap perkara nomor 0311/Pdt.G/2009/PA.SEL. yakni karena gugatan penggugat dapat dikabulkansebagian,makamajelishakim dapat menentukan sebagai berikut:

1. Bahwa Amaq Yang telah meninggal dunia pada tahun 1940 dengan meninggalkan 4 orang anak yaitu Laq Yang, Amaq Jaeng, Inaq Mela, dan Amaq Mahrip.

2. Bahwa Harta warisan Amaq Yang adalah sebagai berikut:

a. Tanah kebun klas II seluas 0,255 ha

b. Tanah sawah klas IV luas 0,600 ha

c. Tanah sawah klas II luas 0,625 ha

d. Tanah sawah klas II luas 1,245 ha

e. Tanah sawah klas I luas 1,660 ha

f. Tanah pekarangan luas 6 are 
3. Bahwa bagiannya masing-masing adalah sesuai dengan ketentuan A1Qur'an surat An-Nisa' ayat (11) jo. Pasal 176 Kompilasi Hukum Islam, bahwa harta warisan dibagi habis oleh anak-anak Amaq Yang dengan Ashabah, dengan ketentuan bagian seorang anak laki-laki sama dengan bagian dua orang anak perempuan.

Menimbang, bahwa oleh karena anak-anakdariAmaq Yangsemuanya telah meninggal dunia, maka bagian mereka masing-masing menjadi bagian ahli warisnya.

Mengingat Hukum Islam dan segala ketentuan perundangundanganyangberlakudanberkaitan dengan perkara ini.

Menetapkan Amaq Yang sebagai pewaris dan anak-anaknya yakni Laq Yang, Amaq Jaeng, Inaq Mela dan Amaq Mahrip sebagai ahli waris. mengingat para ahli waris tersebut juga telah meninggal dunia, maka hakim menetapkan para ahli waris pengganti dari masing-masing ahli waris yang telah meninggal dunia.

MenetapkanhartawarisanAmaq Yang untuk dibagikan kepada ahli waris dan diteruskan kepada ahli waris pengganti tanah sebagaimana disebutkan diatas yakni:

a. Tanah kebun klas II seluas 0,255 ha

b. Tanah sawah klas IV luas 0,600 ha

c. Tanah sawah klas II luas 0,625 ha

d. Tanah sawah klas II luas 1,245 ha

e. Tanah sawah klas I luas 1,660 ha

f. Tanah pekarangan luas 6 are

Menetapkan bagian masing-masing ahli waris Amaq Yang yakni: Laq Yang sebesar 1/6 bagian, Amaq Jaeng sebesar $2 / 6$ bagian, Inaq Mela sebesar $1 / 6$ bagian dan Amaq Mahrip sebesar 2/6 bagian.
Selanjutnya hakim menetapkan bagian masing-masing ahli waris penggantinya.

Antara Munasakhah dan Ahli Waris Pengganti Dalam Perkara Nomor 0311/ Pdt.G/2009/PA.SEL.

Kewarisan merupakan proses peralihan harta kekayaan seseorang kepada orang lain (ahli warisnya). Sistem kewarisan Islam mensyaratkan, timbulnya hak atas kewarisan apabila pewaris (pemilik harta) meninggal dunia, baik meninggal secara hakiki (diketahui secara pasti meninggalnya) atau meninggal secara hukum (atas putusan pengadilan). Apabila seseorang meninggal dunia dengan meninggalkan harta kekayaan, maka berarti ada harta warisan yang harus dibagi-bagikan kepada para ahli waris yang berhak menerimanya. Hukum Islam telah mengatur untuk mensegerakan pembagian warisan kepada yang berhak (ahli warisnya). Tujuannya untuk menghindari seseorang memakan harta anak yatim sebagaimana dijelaskan dalam Qur'an surat An-Nisa ayat (10)

"sesungguhnya orang-orang yang memakan harta anak yatim secara zalim, sebenarnya mereka itu menelan api sepenuh perutnya dan mereka masuk ke dalam api yang menyala-nyala (neraka)".

Seharusnya dalam hukum kewarisan Islam sesaat setelah seseorang meninggal dunia maka harus segera dilakukan pembagian atas harta yang ditinggalkannya tidak harus menunggu seperti kasus diatas, dimana masing-masing ahli waris dalam pasal 147 ayat (2) KHI memiliki hak yang sama sesuai dengan porsinya. Suami/ istri berhak saling mewaris begitupan terhadap anak-anak mereka. Ahli waris seorang suami adalah istri, anak-anaknya dan kedua orang tuanya kalaupun masih hidup. Begitupun ketika istri meninggal dunia maka suami, anak dan kedua orang tuanya menjadi ahli warisnya.

Kasus lain yang sering terjadi adalah ada anak yang meninggal terlebih 
dahulu daripada orang tuanya, padahal anak yang meninggal dunia terlebih dahulu tersebut telah memiliki istri dan anak yang menjadi ahli warisnya. Dalam hukum kewarisan Islam klasik anak yang meninggal dunia terlebih dahulu tersebut tidak memenuhi syarat untuk mendapatkan warisan, sementara anaknyaterhijabolehadanyaanakyanglain dari pewaris (paman dari anak tersebut). Menurut Yusuf Musa, syarat kepastian hidupnya ahli waris pada saat pewaris masih hidup merupakan syarat umum dan mutlak dan disepakati oleh ulama faraidh . Dengan adanya syarat tersebut seseorang sebagai ahli waris dapat terjamin, sebab ahli warislah yang akan menerima perpindahan harta peninggalan orang yang meninggal dunia, dan hal itu tidak mungkin manakala ahli waris tersebut telah meninggal terlebih dahulu dan atau meninggal bersama-sama dengan pewarisnya.

Berkaitan dengan meninggalnya pewaris ada 2 (dua) konsep dalam hukum kewarisan Islam yang pada prinsipnya serupa tetapi tidak sama yakni konsep munasakhah dan ahli waris pengganti. konsep kewarisan munasakhah sudah lebih dahulu dikenal dalam hukum kewarisan Islam klasik. Sedangkan Ahli waris pengganti merupakan "ijtihad kolektif" di Indonesia yang diatur dalam pasal 185 Kompilasi Hukum Islam

\section{Kewarisan Munasakhah}

Al-Munasakhat dalam bahasa Arab berarti memindahkan dan menghilangkan, contohnyadalamkalimatnasakhtual-kitaba bermakna kita menukil (memindahkan) kepada lembaran lain. Menurut AsSayyid Asy-Syarif, munasakhah adalah pemindahan bagian warisan dari sebagian ahli waris kepada orang yang mewarisinya karena kematiannya sebelum pembagian harta warisan dilaksanakan.

Sedangkan Ibnu Umar Al-Baqry mendefinisikan munasakhah sebagai "kematian seseorang sebelum harta dibagibagikan sampai seseorang atau beberapa orang yang mewarisinya menyusul meninggal dunia.

Munasakhah dalam kewarisan ialah kematian seseorang yang sebelum harta peninggalannya dibagi-bagikan, maka terjadi lagi kematian seseorang atau lebih yang berhak meneri-manya, sehingga terjadi pemindahan hak kepada ahli warisnya disebabkan ia meninggal sebelum harta peninggalan pewaris dibagi-bagi.

Untuk lebih jelas system kewarisan munasakhah akan diuraikan melalui ilustrasi gambar berikut ini.

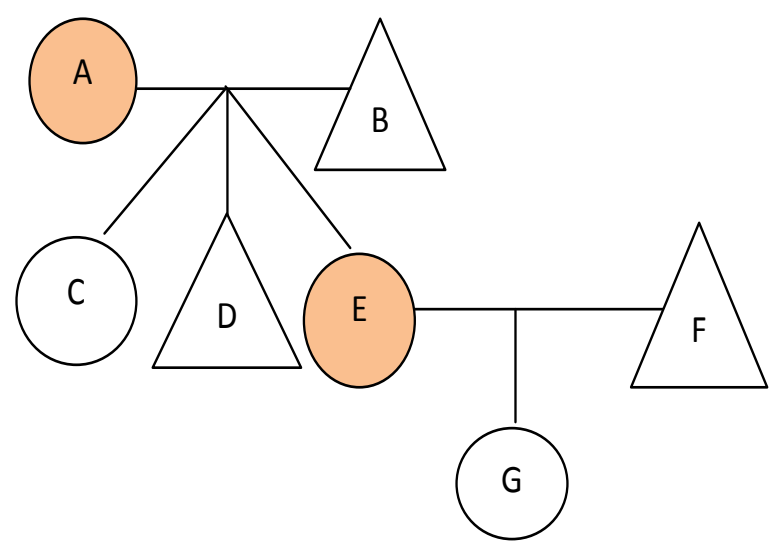

Contoh keterangan gambar:

A (laki-laki) menikah dengan B (perempuan), dari pernikahan tersebut melahirkan 3 (tiga) orang anak yaitu $\mathrm{C}$ (laki-laki), D (perempuan) dan E (lakilaki). Anak laki-laki A yakni E menikah dengan perempuan bernama $F$, dari pernikahan tersebut lahir anak laki-laki bernama G. Tahun 2016, A meninggal dunia tetapi harta warisannya tidak langsung dibagi kepada ahli warisnya yakni B, C, D dan E. Sedangkan F tidak termasuk ahli waris dan G terkena hijab hirman. Tahun 2017 E meninggal dunia dan selanjutnya, tahun 2018 harta warisan A baru dibagikan kepada B, C, D dan $\mathrm{E}$ (walaupun $\mathrm{E}$ telah meninggal dunia pada saat pembagian warisan, akan tetapi E tetap termasuk kategori ahli waris A, karena A meninggal pada saat $\mathrm{E}$ masih hidup). 
Oleh karena E telah meninggal dunia terlebih dahulu pada saat dilakukan pembagian warisan, makabagian warisan $\mathrm{E}$ akan dibagi kepada ahli warisnya yakni B (ibu), F (istri) dan G (anak laki-laki). Sedangkan C dan D terhijab hirman oleh adanya $\mathrm{G}$ sebagai anak laki-laki E.

\section{Kewarisan Ahli Waris Pengganti}

Istilah ahli waris pengganti dalam system kewarisan Islam Indonesia dikenalkan oleh Hazairin dengan istilah mawali. Menurut Hazairin Mawali itu adalah ahli waris karena penggantian, yaitu orang-orang yang menjadi ahli waris karena tidak ada lagi penghubung antara mereka dengan si-pewaris. Ahli waris lainnya yang bukan mawali ialah ahli waris karena tidak ada penghubung antara dia dengan si-pewaris. Maksudnya adalah ahli waris yang menggantikan sesorang untuk memperoleh bagian warisan yang tadinya akan diperoleh oleh orang yang digantikan itu. Sebab orang yang digantikan adalah orang yang seharusnya menerima warisan kalau ia masih hidup, tetapi dalam kasus ini yang bersangkutan dia telah meninggal dunia lebih dahulu dari pada si pewaris. Orang yang digantikan itu hendaklah merupakan penghubung antara dia yang menggantikan dengan pewaris yang meninggalkan harta peninggalan. Lebih jelasnya mereka yang menjadi adalah keturunan anak pewaris, keturunan saudara pewaris atau keturunan orang yang mengadakan semacam perjanjian mewarisi, yang bentuknya dapat saja berupa dalam bentuk wasiat dengan pewaris.

Ahli waris pengganti atau mawali sebenarnya bukan hal baru juga di Indonesia karena sudah dikenal terlebih dahulu dalam Kitab Undang-Undang Hukum Perdata (Burgerlijk Wetbook) hukum perdata Belanda yang diberlakukan di Indonesia dengan istilah Plaatvervulling (pasal 841-848 BW). Menurut Efendi Perangin dalam hukum perdata barat dikenal dalam hal mewarisi langsung yaitu karena diri sendiri (uit eigen hoofde) dan mewaris tidak langsung atau dengan cara mengganti (bij plaatvervulling) ialah mewaris untuk orang yang sudah meninggal terlebih dahulu daripada sipewaris. Ia menggantikan ahli waris yang meninggal lebih dahulu dari si pewaris.

Untuk lebih jelas pewarisan ahli waris pengganti akan dijelaskan dalam gambar sebagai berikut:

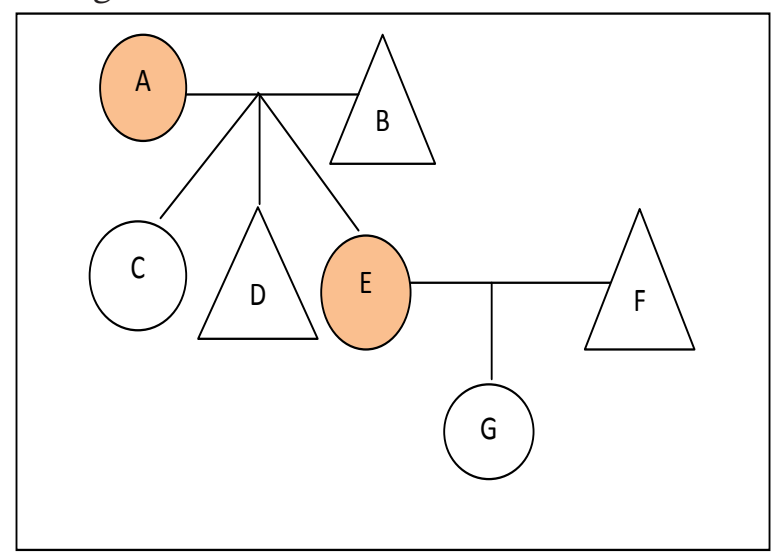

Contoh keterangan gambar:

A (laki-laki) menikah dengan B (perempuan), dari pernikahan tersebut melahirkan 3 (tiga) orang anak yaitu $\mathrm{C}$ (laki-laki), D (perempuan) dan E (lakilaki). Anak laki-laki A yakni E menikah dengan perempuan bernama $\mathrm{F}$, dari pernikahan tersebut lahir anak laki-laki bernama G. Tahun 2016 E meninggal dunia, sedangkan A baru meninggal tahun 2017. Maka kedudukan E sebagai ahli warisnya A digantikan oleh $\mathrm{G}$ sebagai anak dari $\mathrm{E}$ (cucu dari A).

Hukum kewarisan Islam klasik mengatur bahwa cucu tidak dapat menjadi ahli waris kalau masih ada anaknya pewaris yang masih hidup. Anak pewaris tersebut menghijab (menghalang) cucu untuk menjadi ahli waris. Ketentuan tersebut dianggap tidak adil dan sangat merugikan, khususnya bagi cucu yang ditinggal mati oleh ayah/ibunya terlebih dahulu daripada kakeknya ${ }^{1}$.

\footnotetext{
${ }^{1}$ Pada kasus ahli waris pengganti diatas dimana $\mathrm{G}$ tidak dapat menikmati harta warisan dari kakeknya (A) karena bapaknya (E) sudah meninggal terlebih dahulu.
} 
Dari kedua contoh diatas terlihat dalam keadaan tertentu versi fikih tidak adil bila melihat kepada nasib si cucu. oleh karena itu, Prof. Hazairin mengemukakan pendapat yang berbeda dengan pendapat para mujtahid terdahulu. Cucu yang ayahnya lebih dahulu meninggal dapat menempati kedudukan ayahnya dalam mendapatkan harta peninggalan kakek ${ }^{2}$

Dasar argumentasi Hazairin ialah terdapat dalam firman Allah SWT, dalam surah An-Nisa ayat (33).

Artinya: "bagi tiap-tiap harta peninggalan dari harta yang ditinggalkan ibu bapak dan karib kerabat, Kami jadikan pewaris-pewarisnya, dan (jika ada) orang-orang yang kamu telah bersumpah setia dengan mereka, Maka berilah kepada mereka bahagiannya. Sesungguhnya Allah menyaksikan segala sesuatu”.

Hazairin menerjemahkan QS. An-Nisa ayat (33) tersebut sebagai berikut:

a. dan bagi setiap orang itu aku Allah telah mengadakanahli waris (mawali) bagi harta peninggalan ibu bapak dan keluarga dekat (alaqrabun);

b. dan bagi setiap orang itu aku Allah telah mengadakan ahli waris (mawali) bagi harta peninggalan seseorang dengan siapa kamu telah mengikat janji;

c.karena itu (atas alasan tersebut dalam IV:33 huruf a dan b itu) maka berikanlah kepada mereka itu, yakni kepada mawali itu,bagiannya masing-masing. ${ }^{3}$

Ketentuan ahli waris pengganti yang sangat umum dan luas tersebut juga bisa menjadi tidak adil apabila dihadapkan pada kasus misalnya ahli waris yang terdiri dari seorang anak perempuan yang mengurus segala kepentingan ayahnya dalam keadaan susah dan senang dan cucu perempuan melalui anak laki-

\footnotetext{
${ }^{2}$ Amir Syarifuddin, Op.Cit. hlm. 272

${ }^{3}$ Hazairin, Hukum Kewarisan Bilateral menurut Qur'an dan Hadist, Tintamas, Jakarta, 1982, hlm. 8
}

laki yang sama sekali belum mengenal kakeknya yang ayahnya telah lebih dahulu meninggal. Menurut pasal $185 \mathrm{KHI}$ ahli waris pewaris adalah anak perempuan dan cucu yang menggantikan kedudukan ayahnya. Perhitungan bagiannya adalah bagian untuk anak perempuan sebesar $1 / 3$ sedangkan untuk cucu perempuan sebesar 2/3 (karena bagian bagi anak laki-laki yang digantikannya). Apakah ketika terjadi kasus seperti ini pembagian menurut pasal $185 \mathrm{KHI}$ cukup adil atau tidak. Jawabannya jelas sangat tidak adil karena bagian cucu yang tidak memiliki jasa apapu terhadap pewaris mendapatkan bagian warisan lebih besar daripada anak perempuan yang sangat berjasa terhadap pewaris. Sedangkan apabila dibandingkan dengan pembagian menurut hokum Islam klasik untuk kasus yang sama adalah bagian untuk cucu perempuan (karena kedudukannya sendiri/bukan karena menjadi ahli waris pengganti) sebesar $1 / 6$ (karena mewaris bersama dengan anak perempuan), sedangkan bagian untuk anak perempuan sebesar $1 / 2$. Dan sisanya sebesar $1 / 3$ untuk anak dengan hak radd 4 , jadi keseluruhannya menjadi $5 / 6$.

Ketentuan ahli waris pengganti sebagaimana diatur dalam pasal 185 KHI tersebut, menurut Yahya Harahap memang merupakan terobosan terhadap penyelewengan hak cucu atas harta warisan ayah, apabila ayah meninggal lebih dahulu dari pada kakek. Akan tetapi yang perlu diperhatikan dari Pasal 185 ini adalah bahwa isi pasal tersebut tidak bersifat imperatif (selalu digantikan) oleh anaknya. Tetapi pasal 185 ini bersifat tentatif atau alternatif. Hal mana diserahkan kepada pertimbangan hakim

${ }^{4}$ Radd adalah penambahan pada bagian-bagian ahli waris dan pengurangan pada saham-sahamnya. jadi radd terjadi karena ada kelebihan setelah diadakan pembagian. Sisa hasil pembagian harta tersebut dikembalikan kepada ahli waris yang shahibul fard atau ahli waris yang memiliki hubungan darah secara langsung dengan pewaris. Lihat Fatchur Rahman, Op. Cit. hlm. 423 dan Suhrawardi K. Lubis, Komis Simanjuntak, Hukum Waris Islam (Lengkap \& Praktis), Sinar Grafika, Jakarta, 2004, hlm. 165-166 
Pengadilan Agama menurut kasus demi kasus. Hal ini bisa dilihat dari kata "dapat" dalam pasal tersebut. Sifat alternatif atau tidak imperatif dalam Pasal 185 sudah tepat, sebab tujuan dimasukkannya ahli waris pengganti dalam KHI karena melihat pada kenyataan dalam beberapa kasus, kasihan terhadap cucu atau cucucucu pewaris ${ }^{5}$.

\section{Analisis Hukum Terhadap Putusan Pengadilan Agama Selong Nomor 0311/ Pdt.G/2009/PA.SEL.}

Pengadilan Agama merupakan salah satu pelaku kekuasaan kehakiman yang diberikan kewenangan untuk memeriksa, memutus dan menyelesaikan perkaraperkara orang-orang yang beragama Islam dan atau badan hukum syariah di bidang tertentu yaitu: Perkawinan, Kewarisan, Wasiat, Hibah, Wakaf, Zakat, Infaq, Shadaqah, dan Ekonomi Syariah. Kewenangan tersebut sebagaimana dijelaskan dalam pasal 2 junto pasal 49 Undang-Undang Nomor 3 tahun 2006 tentang Perubahan Atas Undang-Undang Nomor 7 tahun 1989 tentang Peradilan Agama.

Kewenangan Pengadilan Agama di bidang kewarisan menurut penjelasan pasal 49 huruf b bahwa yang dimaksud dengan "waris" adalah penentuan siapa yang menjadi ahli waris, penentuan mengenai harta peninggalan, penentuan bagian masing-masing ahli waris, dan melaksanakan pembagian harta peninggalan tersebut, serta penetapan pengadilan atas permohonan seseorang tentang penentuan siapa yang menjadi ahli waris, penentuan bagian masingmasing ahli waris. Sedangkan tentang hukum yang digunakan dalam menyelesaiakan urusan kewarisan tersebut adalah menggunakan Hukum Islam. Hal ini didasarkan dihapuskannya

${ }^{5}$ Yahya Harahap, "Informasi Materi KHI, Mempositifkan Abstraksi Hukum Islam" Dalam Mimbar Hukum : Aktualisasi Hukum Islam, No.5, Al Hikmah, Jakarta, 1992, hlm. 25 "hak opsi" atau hak memilih para pihak yang berperkara untuk memilih membagi warisan menggunakan hukum mana yang dikehendakinya. Ketentuan dihapuskannya hak opsi tersebut diatur pada penjelasan umum alinea ke II UU No. 3 tahun 2006. Hal ini berarti sesuai dengan fungsi Peradilan Agama merupakan peradilan yang dikhususkan untuk menyelesaikan sengketa antara orang-orang yang beragama Islam. Penyelesaian sengketa tersebutpun wajib menggunakan hukum Islam. Selanjutnya sesuai dengan salah satu asas dalam beracara di peradilan agama yakni asas Personalitas Keislaman bahwa yang tunduk dan dapat ditundukkan kepada kekuasaan lingkungan peradilan agama hanya mereka yang mengaku pemeluk agama Islam. Bagi penganut agama lain tidak tunduk atau tidak dapat dipaksakan untuk tunduk pada Pengadilan Agama, kecuali bagi yang non-muslim atas kerelaan mereka sendiri tunduk pada hukum islam ${ }^{6}$

Apabila dilihat dari rangkaian kasus hingga sampai keluar putusan Pengadilan Agama Selong Nomor 0311/ Pdt.G/2009/PA.SEL. maka peneliti dapat meringkasnya sebagai berikut: kasus ini berawal dari meninggalnya Amaq Yang pada tahun 1940. Menurut pengakuan penggugat dalam gugatanya, bahwa setelah meninggalnya Amaq Yang tahun 1940 tersebut, maka selama kurang lebih 69 tahun harta warisan Amaq Yang dikuasai oleh 2 (dua) anak laki-laki Amaq Yang yakni Amaq Jaeng dan Amaq Mahrip dan setelah mereka meninggal diwariskan kepada anak-anaknya sedangkan 2 (dua) anak perempuan Amaq Yang yakni Laq Yang (Inaq Maja) dan Inaq Mela dan anak-anaknya tidak diberikan hak memanfaatkan apalagi memilikinya. Begitupun dengan pembagian warisan

${ }^{6}$ Fatahullah, S. H. "PLURALITY OF SHARIAH BANKING DISPUTE SETTLEMENT METHOD IN INDONESIA." Jurnal IUS (Kajian Hukum dan Keadilan) 2.3 (2014). hlm. 543 
Amaq Yang belum sama sekali dilakukan, baik dibagi menurut hukum adat maupun hukum agama Islam. Atas dasar kondisi tersebut maka pada tanggal 10 maret 2009 Inaq Terum binti Amaq Mera yakni anak perempuan Inaq Mela binti Amaq Yang mengajukan gugatan hukum di Pengadilan Agama Selong Kabupaten Lombok Timur NTB dengan nomor perkara 0311/Pdt.G/2009/PA.SEL. Di dalam gugatannya pada intinya penggugat memohon kepada majelis hakim Pengadilan Agama untuk menetapkan ahli waris dari almarhum Amaq Yang, menetapkan harta peninggalan Amaq Yang sebagai harta warisan, menyatakan dan menetapkan bahwa perbuatan hukum mengalihkan dan memindahtangan harta peninggalan Amaq Yang adalah perbuatan yang tidak sah, menetapkan bagian masing-masing ahli waris Amaq Yang dan menghukum kepada kepada para tergugat untuk membayar semua biaya yang timbul akibat perkara ini.

Dalam proses persidangan yang bertempat di Pengadilan Agama Selong Kabupaten Lombok Timur NTB menurut pengakuan para Tergugat 1-6, 17, 21-24 dalam jawaban atas gugatan Penggugat, bahwa:

a. tanahpekarangansengketano.6dikuasai Inaq Munaen dan Inaq Dusuki adalah cucu-cucu dari Inaq Maja (Laq Yang).

b. terhadap tanah-tanah objek gugatan Penggugat pernah terjadi perdamain di Desa Suralaga yaitu pada Tanggal 12 Januari 1961 antara anak-anak dan cucu almarhum Amaq Yang yaitu Inaq Yang (Laq Yang alias Inaq Maja sendiri), Almarhum Amaq Jaeng diwakili oleh anak-anaknya yaitu Inaq Sahlim alias Inaq Ruhun, Inaq Misrun, Laq Hawiyah alias Inaq Judin (Inaq Sirojudin), Inaq Mela (ibu penggugat) dan Amaq Mahrip. Inti dari kesepakatan damai tersebut adalah Laq Yang alias Inaq Maja dan Inaq Mela (ibu penggugat) tidak mau menerima tanah dan hanya mau menerima pesangon selama hidupnya, pesangon tersebut dibebankan kepada Amaq Mahrip dan anak-anak Amaq Mahrip sampai Inaq Maja dan Inaq Mela meninggal dunia.

d. dalamsuratperdamaiandengantandacap jempol tanggal 12 Januari 1961 tersebut Inaq Maja dan Inaq Mela diberikan hak mengelola tanah sawah seluas lebih kurang 1,245 ha (tanah sengketa no. 4) untuk menjadi pesangon selama hidup mereka dan terhadap pemeliharaan hidup kesehatan sampai dengan kematiannya tetap menjadi tanggung jawab Amaq Mahrip dan anak-anaknya.

f. terhadap objek perdamaian yang dilakukan pada tanggal 12 Januari 1961 pernah diuji dan digugat oleh anak dari almarhum AmaqJaengyaituInaq Sahlim alias Inaq Ruhun dan Laq Hawiyah alias Inaq Judin (Inaq Sirojudin) menggugat Amaq Mahrip dan dua anaknya yaitu Loq Rasa alias Amaq Mardiun alias $\mathrm{H}$. Anwar dan Amaq Nursehan alias $\mathrm{H}$. Nurudin di Pengadilan Negeri Selong. Gugatan tersebut diputus oleh PN Selong pada tanggal 30 maret 1978 no. 53/PN.SEL/1978/PDT yang amar putusannya menolak gugatan Penggugat seluruhnya.

g. setelah ditolaknya gugatan di PN Selong tersebut Amaq Mahrip pada tanggal 13 oktober 1982 memberikan lagi tanah sebanyak 42 are kepada Inaq Sahlim alias Inaq Ruhun dan Laq Hawiyah alias Inaq Judin (Inaq Sirojudin). sedangkan pesangon terhadap Laq Yang alias Inaq Maja dan Inaq Mela tetap berlangsung. Mengenai perdamaian, baik perdamain I tanggal 12 Januari 1961 dan perdamaian II tanggal 13 oktober 1982 diakui benar terjadi oleh Turut Tergugat I (H. Nurudin bin H. Rosidi) atau keponakan dari Penggugat yang disampaikan dalam jawaban secara tertulis, dan Turut Tergugat I merasa tidak berkeberatan dengan isi perdamain tersebut, karena baik Laq Yang alias Inaq Maja maupun 
Inaq Mela (nenek Turut Tergugat I) telah menerima pesangon berupa hasil tanah seluas 1,250 ha yang dinikmati selama hidupnya. Tanah pesangon dikerjakan oleh anak-anak Laq Yang alias Inaq Maja dan Inaq Mela dan hasilnya digunakan untuk kebutuhan Laq Yang alias Inaq Maja maupun Inaq Mela selama hidupnya.

Jadi menurut peneliti karena Turut Tergugat I merupakan keturunan langsung Inaq Mela (cucunya) maka dia sangat tahu persis tentang tanah yang dijadikan pesangon karena besar kemungkinan tanah tersebut digarap oleh orang tuanya dan hasilnya gunakan untuk membiayai kebutuhan hidup Inaq Mela (orang tua penggugat). Apalagi orang tua dari Turut Tergugat I merupakan anak laki-laki tertua dari Inaq Mela. Seharusnya menurut peneliti pengakuan ini perlu diperhatikan dengan seksama oleh menjadi majelis hakim dan menjadi pertimbangan utama dalam memutus kasus tersebut. Apalagi mengenai pemberian pesangon tersebut secara tidak langsung diakui sendiri oleh Penggugat dalam Repliknya pada No. 6 dengan kata-kata "dengan adanya pesangon bukan menyebabkan Penggugat tidak dapat menggugat hak waris ibunya", selanjutnya Penggugat melanjutkan "dan pesangonnya belum jelas apakah sudah diterima atau belum oleh ibunya Penggugat". Dari pernyataan ini membuktikan bahwa Penggugat tidak tahu secara pasti perdamaian dan pesangon yang berikan kepada ibunya. Hal inipun tidak bisa dibuktikan oleh Penggugat dan saksinya. Peneliti beranggapan bahwa lebih kuat pengakuan Turut Tergugat I yang secara jelas mengakui adanya perdamaian dan pesangon daripada bantahan tidak adanya perdamaian dan pesangon menurut Penggugat yang masih ragu dengan argumentasi bantahannya. Apalagi mengenai perdamaian ini diakui dan dikuatkan oleh putusan PN Selong dengan nomor perkara 53/PN.SEL/1978/ PDT. Putusan tersebut dalam hukum acara dapat dijadikan sebagai alat bukti yang sah dan mempunyai nilai kekuatan pembukatian yang memaksa (dwingende bewijskracht). Alat bukti tersebut tidak bisa lagi dilumpuhkan oleh pihak lawan (tegen bewijs). Hakim sendiripun terikat secara mutlak atas alas bukti tersebut ${ }^{7}$. Disamping bukti putusan PN Selong tersebut Tergugat juga menyertakan bukti photo surat perdamain (T.1) untuk memperkuat jawaban/argumentasinya.

Disamping itu apabila dilihat rangkaian kasusnya maka menurut peneliti tidak bisa mutlak/langsung menggunakan konsep ahli waris pengganti. Akan tetapi menggunakan konsep munasakhah setidaknya untuk pembagian pada ahli waris pertama, dengan alasan:

a. Konsep munasakhah dijelaskan sebelumnya bisa terjadi apabila pewaris meninggal dunia akan tetapi harta warisannya tidak langsung dibagikan kepada ahli waris disebabkan karena pertimbangan dan berbagai hal, selanjutnya ada ahli warisnya yang menyusul meninggal dunia sehingga ahli warisnya tersebut meninggalkan hak warisnya. Dalam kasus yang diputus olehmajelishakimdengannomorperkara 0311/Pdt.G/2009/PA.SEL.pewarisyang bernama Amaq Yang meninggal Tahun 1940, harta warisannya tidak langsung dibagikan kepada para ahli warisnya yaitu Laq Yang, Amaq Jaeng, Inaq Mela dan Amaq Mahrip, akan tetapi dikuasai sepenuhnya oleh 2 (dua) ahli waris lakilaki Amaq Yang yaitu Amaq Jaeng dan AmaqMahrip.SampaimeninggalnyaLaq Yang dan Inaq Mela belum memperoleh bagianwarisandaribapaknyayaituAmaq Yang. Selanjutnya secara terus menerus dan turun temurun harta warisan Amaq Yang tersebut dikuasai oleh keturunan Amaq Jaeng dan Amaq Mahrip dan

${ }^{7}$ M. Yahya Harahap, Kedudukan Kewenangan dan Acara Peradilan Agama UU No. 7 Tahun 1989, ed. kedua cet. kelima, Sinar Grafika, Jakarta, 2009, hlm. 240 
sebagian ada yang sudah berpindah tangan melalui jual beli.

b. Penggunaanhukumahliwarispengganti dalam kasus tersebut bertentangan dengan hukum materiil khususnya hukumIslam,karenaahliwarispengganti tidak dikenal dalam hukum dan fiqh Islam. Hukum dan fiqh Islam sudah sangat jelas dan terperinci mengatur cara pembagian warisan. Berdasarkan ayat-ayat kewarisan yang terperinci dan mendetail, lahirlah asas Ijbari sebutan bagi peralihan harta dari orang yang telah meninggal kepada orang yang masih hidup berlaku dengan sendirinya. Kata ijbari mengandung arti paksaan, artinya harta pewaris beralih dengan sendirinya sesuai dengan yang sudah Allah SWT tetapkan, baik siap yang mendapatkan harta tersebut maupun besarnya bagian masing-masing pihak. ${ }^{8}$ Tinggal selanjutnya umat Islam yang harus tunduk dan patuh terhadap apaapa yang sudah digariskan oleh Allah dan Rasul-Nya tersebut. Hal ini sejalan dengan teori Kredo dan Kedaulatan Tuhan. $^{9}$

c. Menggunakan pasal 185 KHI bukan merupakansuatukeharusan(imperatif), hal ini dapat dilihat dari kata "dapat" pada pasal tersebut. Penggunaan pasal tersebut oleh hakim merupakan jalan terakhir yang ditempuh untuk mencapai keadilan. Apalagi dalam kasus tersebut tidakadaurgensinyamenggunakanpasal $185 \mathrm{KHI}$ tersebut.

d. Dalam putusan kasus nomor 0311/ Pdt.G/2009/PA.SEL. hakim tidak

\footnotetext{
${ }^{8}$ Habiburrahman, Rekonstrukis Hukum Kewarisan Islam di Indonesia, Kencana Prenada Media Group, Jakarta, 2011, hlm. 194-195

${ }^{9}$ Menurut teori kredo, seseorang yang menganut suatu keyakinan atau agama diharuskan tunduk dan patuh kepada hukum agama yang dianutnya. Teori lain yang mendukung teori kredo adalah teori autoritas hukum yang diperkenalkan oleh H.A.R. Gibb, ia mengatakan bahwa seseorang harus tunduk kepada hukum agama yang dianutnya (someone has an obligation to obey his own religious rules). Adapun teori kedaulatan Tuhan dikembangkan oleh Abul 'Ala al-Maududi (1903-1983), ia menjelaskan bahwa Tuhan merupakan sang Mahatunggal yang paling otoritatif dalam prinsip hukum. lihat Habiburrahman, Ibid. hlm. 21-22
}

konsisten dalam menetapkan ahli waris yakni tidak memperhitungkan bagian warisan bagi ahli waris yang tidak memiliki anak (puntung) dan sudah meninggal. Padahal mungkin saja ahli waris tersebut masih memiliki suami sebagai ahli warisnya (pewarisan karena hubungan perkawinan). Contohnya adalah ahli waris Aceh dan ahli waris Inar.

e. Majelis hakim dalam putusannya mengenyampingkan dan tidak mempertimbangkan sama sekali perdamaiandanpesangonyangdiberikan oleh sebagian ahli kepada ahli waris yang lain. Padahal perdamaian dan pesangon tersebut telah dikuatkan oleh putusan PN Selong No. 53/PN.SEL/1978/PDT. Dalam hukum waris Islam perdamaian yang disertai dengan pemberian prestasi (dalam kasus ini pesangon) kepada sebagian ahli waris dikenal dengan takharuj. Takharuj, adalah suatu perjanjian yang diadakan oleh para ahli waris untuk mengundurkan (mengeluarkan) salah seorang ahli waris dalam menerima bagian pusaka dengan memberikan suatu prestasi, baik prestasi tersebut berasal dari harta milik orang yang pada mengundurkannya, maupun berasal dari harta peninggalan yang bakal dibagi-bagikan ${ }^{10}$. Disebut takharuj karena adanya mutakharaj yaitu pihak yang diundurkan, setelah setelah diberi prestasi atau imbalan oleh seseorang atau beberapa orang ahli waris lainnya ${ }^{11}$. Pada hakikatnya, takharuj termasuk kedalam salah satu bentuk penyesuaian dalam pelaksanaan hukum Islam $^{12}$. Dalam pelaksanaan praktis, harta warisan dibagi sesuai dengan kerelaan bersama atas dasar kebutuhan masingmasing. setiap ahli waris memiliki hak

\footnotetext{
${ }^{10}$ Fathur Rahman, Op.Cit. hlm. 468

${ }^{11}$ Suparman Usman \& Yusuf Somawinata, Op. Cit. hlm. 151

${ }^{12}$ Rahmadi Usman, Hukum Kewarisan Islam dalam Dimensi Kompilasi Hukum Islam, Mandar Maju, Bandung, 2009, hlm. 135.
} 
masing-masing untuk bertindak atas harta warisannya sesuai kemauan dan kerelaannya. ${ }^{13}$ Penyelesaian pembagian warisan dengan cara takharuj tersebut merupakan bentuk kesepakatan atas kerelaan dalam membagi warisan. Hal ini juga sejalan dengan pasal $183 \mathrm{KHI}$ yang berbunyi:

"para ahli waris dapat bersepakat melakukan perdamaian dalam pembagian warisan, setelah masing-masing menyadaribagiannya".

Ada 3 (tiga) bentuk takharuj yaitu:

- seorangahliwarismengundurkanahli waris yang lain dengan memberikan sejumlah uang atau barang yang diambilkan dari miliknya sendiri;

- beberapa orang ahli waris mengundurkan seorang ahli waris dengan memberikan prestasi yang diambilkan dari harta peninggalan itu sendiri;

- beberapa orang ahli waris mengundurkan seorang ahli waris dengan memberikan prestasi yang diambilkan dari harta milik mereka masing-masing secara urunan. ${ }^{14}$

\section{SIMPULAN}

Kesimpulan terhadap pembahasan dari permasalahan diatas adalah pertama, majelis hakim yang memeriksa dan memutus perkara Nomor 0311/ Pdt.G/2009/PA.SEL. menggunakan konstruksi hukum Ahli Waris Pengganti didalam pasal 185 KHI. Disebabkan karena ahli waris utamanya (anak-anak pewaris) telah meninggal dunia semua sebelum harta warisan dibagi-bagikan. kedua, majelis hakim menjadikan pasal 185 KHI sebagai suatu yang imperatif dan bukan pilihan, padahal dalam perkara ini tidak cocok menggunakan konsep ahli waris pengganti, dan dari analisis yang dilakukan ada beberapa hal yang diabaikan oleh hakim misalnya tidak

\footnotetext{
${ }^{13}$ Amir Syarifuddin, Op. Cit. hlm. 301

${ }^{14}$ Fathur Rahman, Op.Cit. hlm. 471-472
}

mempertimbangkan nilai kemanfaatan dan mengabaikan takharuj yang terjadi antar ahli waris.

Adapun saran/rekomendasi yang dapat berikan adalah pertama, hakim yang memeriksa dan memutus suatu perkara hendaknya cermat dalam menggunakan pertimbangan hukum suatu kasus karena ini menyangkut pemberian keadilan yang seadil-adilnya kepada pencari keadilan (para pihak yang berperkara). kedua, Pasal $185 \mathrm{KHI}$ tentang ahli waris pengganti perlu dipertimbangkan untuk dilakukan revisi karena tidak jelas batasan penggantian tempatnya dan tidak sejalan dengan hukum waris Islam yang dikenal selama ini, dan untuk memberikan keadilan kepada ahli waris cucu yang orang tuanya meninggal duluan sebelum pewaris meninggal dan posisinya terhijab dapat menggunakan konsep wasiat wajibah.

\section{DAFTAR PUSTAKA}

\section{Buku:}

Amir Syarifuddin, 2004: Hukum Kewarisan Islam, Kencana, Jakarta

Al Yasa Abu Bakar, 1998, Ahli Waris Sepertalian Darah, Kajian Perbandingan Terhadap Penalaran Hazairin Dan Penalaran Fikih Mazhab, INIS, Jakarta

Elvi Lusiana, 2011: Cara Mudah dan Benar Membagi Harta Warisan, QultumMedia, Jakarta

Fatchur Rahman, 1971: Imu Waris, PT. Al-Ma'arif, Bandung

Hazairin, 1982: Hukum Kewarisan Bilateral menurut Qur'an dan Hadist, Tintamas, Jakarta

H. A. Sukris Sarmadi, 2012: Dekonstruksi Hukum Progresif Ahli Waris Pengganti Dalam Kompilasi Hukum Islam, Aswaja Pressindo, Yogyakarta

Habiburrahman, 2011: Rekonstrukis 
Fatahullah, Sugiyarno \& Ita Surayya|Antara Munasakhah Dan Ahli Waris Pengganti Pada Putussan.......

Hukum Kewarisan Islam di Muh. Sudirman, Munasakhah Dalam Indonesia, Kencana Prenada Media Group, Jakarta

M. Yahya Harahap, 2009: Kedudukan Sistem Kewarisan Islam, Jurnal Supremasi, Volume XI Nomor 2, Kewenangan dan Acara Peradilan Oktober 2016 Agama UU No. 7 Tahun 1989, ed. kedua cet. kelima, Sinar Grafika, Jakarta

Muhammad Ali Ash-Shabhuni, 1995: Pembagian Waris Menurut Islam, Penerjemah A.M. Basamalah, Gema Insani Press, Jakarta

Rahmadi Usman, 2009: Hukum Kewarisan Islam dalam Dimensi Kompilasi Hukum Islam, Mandar Maju, Bandung

Suparman Usman dan Yusuf Somawinata, 2008 : Figh Mawaris Hukum Kewarisan Islam, Gaya Media Pratama, Jakarta

Sayuti Thalib, 1987: Hukum kewarisan Islam di Indonesia, Bina Aksara Cet. III Jakarta

Suhrawardi K. Lubis dan Komis Simanjuntak, 2004: Hukum Waris Islam (Lengkap \& Praktis), Sinar Grafika, Jakarta

\section{Jurnal:}

Fatahullah, S. H. "PLURALITY OF SHARIAH BANKING DISPUTE SETTLEMENT METHOD IN INDONESIA." Jurnal IUS (Kajian Hukum dan Keadilan) 2.3 (2014).

Wahidah, Kasus Munasakhah Pada Tiga Kabupaten Di Kalimantan Selatan, Jurnal Tashwir Vol. 3 No. 8, Oktober - Desember 2015

M. Yahya Harahap, 1992, "Informasi Materi KHI, Mempositifkan Abstraksi Hukum Islam" Dalam Mimbar Hukum : Aktualisasi Hukum Islam, No.5, Al Hikmah, Jakarta 